Int. J. Morphol.,

28(2):389-392, 2010

\title{
Cephalic Index of Ogbia Tribe of Bayesla State
}

\author{
Índice Cefálico de la Tribu Ogbia del Estado de Bayelsa
}

"Eroje, M. A.; "Fawehinmi, H. B.; "Jaja, B. N. \& ** Yaakor, L.

EROJE, M. A.; FAWEHINMI, H. B.; JAJA, B. N. \& YAAKOR, L. Cephalic index of Ogbia tribe of Bayesla state. Int. J. Morphol., 28(2):389-392, 2010.

SUMMARY: A study on Cephalic Index was carried out on subjects from Ogbia tribe of Bayelsa State in the Niger Delta region of Nigeria. Four hundred and fourty individuals were randomly selected from the community comprising of 219 males and 221 females respectively. The ages of the subjects ranged from 2-18 years. The length and breadth of the head was measured using a sliding caliper from standard bony landmarks. The measurable point for head length was measured between the glabella and opisthocranion while the head breadth was the widest biparietal diameter from euryon (eu) on one side of the head to euryon (eu), on the other side. Mean values of cephalic index, standard deviation and standard error of mean were calculated for both sexes. The result showed that the mean cephalic index was $72.96 \pm 6.12$. Male had a cephalic index of $73.68 \pm 6.53$ while female had a cephalic index of $72.24 \pm 5.60$. The difference in cephalic index between male and female was significant $(\mathrm{p}=0.007)$. Based on the cephalic index, the head form of $66.82 \%$ of individuals were Dolichocephalic, 21.59\% Mesocephalic, 10.23\% Brachycephalic and 1.36\% Hyperbrachycephalic. This research showed that Ogbia children have Dolichocephalic phenotype. The data from this research will be useful in anthropology, genetics and forensic medicine.

KEY WORDS: Cephalic index; Dolichocephalic; Ogbia; Forensic Medicine.

\section{INTRODUCTION}

Ogbia people are an indigenous people of Bayelsa state in the Niger Delta region of Nigeria. Ogbia town is noted for its large deposit of crude oil as it houses the first oil well in Nigeria. Cephalic index is a useful anthropometric parameter utilized in the determination of racial variations. It is also used to determine sexual differences especially in individuals whose identity are unknown (Shah \& Jadhav, 2004). It is one of the clinical anthropometric parameter recognized in the investigation of craniofacial skeleton because of its validity and practicality (Grant \& Peter, 2003).

Cephalic index is the most frequently investigated craniofacial parameters as it utilizes the length and breath of the head which are useful indices in the study of secular trend (Larsen, 1997; Kouchi, 2000). The ratio of the maximum head breadth to the maximum head length can be used to measure the size of the head (Kelly et al., 1999). Cephalic index gives an idea of how genetic characters are transmitted between parents, offspring and siblings (Shah \& Jadhav). It is inherited in a unitary fashion (Sekla \& Soukup, 2005).
On basis of cephalic index, head shapes group to four international categories, which are dolichocephal, brachycephal, mesocephal and hyperbrachycephal (Williams et al., 1995; del Sol, 2005). Cephalic index is recognized in determining the variations in shape of the head and face in newborns (Golalipour et al., 2005). It is also useful in determining head dimensions in fetuses (Rajlakshmi et al., 2001).

In a work on secular changes in head dimensions of Japanese females over eight decades cephalic index was found to have decreased over the last two decades in adult Japanese females (Golam et al., 2004). Investigations carried out on secular change in body height and cephalic index of Croatian medical students revealed a significant increase of dolichocephalic and mesocephalic and a significant decrease of brachycephalic head shape in both sexes suggesting a continuity of the debrachycephalization process (Buretic'Tomljanovic' et al., 2003).

In a study in Gurung community of Nepal (Lobo et al., 2005) calculated cephalic index for male as 83.1 while

\footnotetext{
* Department of Anatomy, Niger Delta University, Wilberforce Island, Amassoma, Bayelsa State, Nigeria.

** Department of Anatomy, University of Port Harcourt, Rivers State, Nigeria.
} 
that of female was 84.6 , this was statistically significant. They were classified as brachycephalic. In another study by Oladipo \& Olotu, 2006, on cephalic indices of Ijaw and Igbo ethnic groups of Nigeria, Ijaw male was found to belong to brachycephalic group while Ijaw female, Igbo male and Igbo female were mesocephalic. Futher more, cephalic index was recorded as $80.4 \pm 4$ amongst Turkman Males in GorganNorth of Iran (Golalipour et al., 2007)

The cephalic index of Ogbia people of Bayelsa state has not been documented. This study aimed at applying internationally accepted methods to ascertain the standard value of the cephalic index of Ogbia people of Bayelsa state in the Niger Delta region of Nigeria to provide a baseline data of cephalic index which could be vital in forensic and anthropological studies.

\section{SUBJECTS AND METHOD}

For the present study, 440 school children (221 Female and 219 Male) were selected as subjects. The age of the students ranged from 2 to 18 years. The Head Length (Greatest anteroposterior diameter) was measured with the help of spreading caliper, from glabella to opisthocranion. The headbreadth was measured as the maximum transverse diameter between two fixed points of the parietal bone. All the measurements were taken with the subject in relaxed condition and head in anatomical position. For subjects with their heads done, they had their hair parted before measurement. Measurements were taken to the nearest centimeter and parallax was avoided in the visual read out so as to reduce error in the measurement. Cephalic index was calculated using the following equation (Golalipour et al., 2003).

Cephalic index $=$ Maximum head breadth $\mathrm{x} 100$ Maximum head length

The data collected was statistically analyzed using student t-test.

\section{RESULTS}

Mean and SD of cephalic index in Ogbia people of Bayelsa State was $72.96 \pm 6.12$. The morphological classification of the head was done according to the cephalic index. Among Ogbia people, the dominant type was dolichocephalic with a frequency of $66.82 \%$ and the rare type was hyperbrachycephalic with frequency of $1.36 \%$ (Table I). The mean cephalic index for male is $73.68 \pm 6.53$ (S.E. 0.44) and for female is $72.24 \pm 5.60$ (S.E. 0.38). This difference was statistically significant $(\mathrm{p}=0.007)$ using student t-test from Graphpad Instat Demo Software. Table II shows comparison of cephalic index from different studies.

Table I. The distribution of different head types.

\begin{tabular}{lrc} 
Head type & $\mathbf{N}$ & $\boldsymbol{\%}$ \\
Dolichocephalic & 294 & 66.82 \\
Mesocephalic & 95 & 21.59 \\
Brachycephalic & 45 & 10.23 \\
Hyperbrachycephalic & 6 & 1.36 \\
\hline
\end{tabular}

\section{DISCUSSION}

This study showed that the cephalic index of male was significantly higher than those of female $(p=0.007)$, the reason for this difference cannot be immediately explained but it agrees with sexual dimorphism as reported by Olotu et al. (2009). The cephalic index of this study was lower than Fawehinmi et al. study in Port Harcourt, Nigeria with 79.80 (Fawehinmi et al., 2008).

Oladipo \& Olotu determined the cephalic index for Ijaw male and female as 80.98 and 78.24 respectively. They also worked out the cephalic index of Igbo male and female as 79.04 and 76.83 respectively. Their findings were higher than that of Ogbia male and female.

Table II. Comparision of cephalic index with other population.

\begin{tabular}{llll}
\hline 1 & Bhargava \& Kher, 1960. & Bhils of Central India & 76.98 \\
2 & Bharg ava \& Kher, 1961. & Berelas of Central India & 79.80 \\
3 & Shah \& Jadhav, 1960. & Gujarat, India & 80.81 \\
4 & Del Sol, 2005. & IX Región of Chile & 80.42 \\
5 & Golalipour et al., 2007. & Turkman, Iran & 80.40 \\
6 & Fawehinmi et al., 2008. & Port Harcourt, Nigeria & 79.80 \\
7 & Present study. & Ogbia, Nigeria & 72.96 \\
\hline
\end{tabular}


Cephalic index from the present study was lower than Abolhasanzadeh \& Farahani (2003) study in Tehran- Iran with 75 , Shah \& Jadhav study in India with 80.42 , and a study in Chile (80.42) by del Sol. Cephalic index from our study was also lower than a study in native Fars males with 84.8 (Golalipour et al.).

In our study, we observed gender difference with male (73.68) having a higher cephalic index compared to female (72.24). Investigations carried out on the cephalic index of male and female of Gurung community in Nepal revealed a significant gender difference (Lobo et al.), with male having a cephalic index of 83.1 which is lower than female with cephalic index of 84.6. This implies that cephalic index can be higher in any sex depending on the peculiarity of the population under study.

In our study, dominant type of head shape was dolichocephalic (66.82\%). This finding is similar to another study in India (Bhatia et al., 1995) in which $58.5 \%$ of population was dolicocephalic. Dominant type of head from this study is not similar to del Sol study in Chile, Bhargava \& Kher study in central Indian (Bhargava \& Kher, 1960), Oladipo's study of Ijaw and Igbo tribes of Nigeria (Oladipo \& Olotu) and Fawehinmi's study in Port Harcourt, Nigeria (Fawehinmi et al.) with mesocephalic type (Table II).

Also, the dominant head type was reported as brachycephalic in Turkman of Iran (Golalipour et al., 2007), IX Region of Chile (del Sol) and in Gujarat, India (Shah \& Jadhav).
It is worthy to note that the percentage of head types also varies in different populations. In a study on 50 individuals in the IX Region of Chile, del Sol reported that $66 \%$ of the individuals were mesocephalic, $28 \%$ brachycephalic, $4 \%$ hyperbrachycephalic and $2 \%$ dolichoephalic.

Besides, in a study in India on 302 male students, it was shown that $41 \%$ of the students were mesocephalic, $37 \%$ brachycephalic, $14 \%$ hyperbrachycephalic, and $7 \%$ dolichocephalic (Shah \& Jadhav). In the present study, 66\% of subjects were dolichocephalic, $21 \%$ mesocephalic, $10 \%$ brachycephalic while $1 \%$ hypercephalic.

The percentage of head shape observed in the different study may not be unconnected with hereditary factor. Environment may also have a secondary effect (Golalipour $e t$ al., 2007). The kind of diet taken could also play a role in influencing the dominant head shape.

Head shapes can also change from one generation to the other. For instance, in the first generation of Japanese immigrants in Hawaii it was noticed that they had an increased head breadth, a decreased head length and a higher cephalic index than their parents (Heravi \& Zieaee, 2002).

In conclusion, this study shows a significant increase of dolichocephalic and mesocephalic and a significant decrease of brachycephalic and hyperbrachycephalic head shape in both sexes. Our results suggest a continuity of debrachycephalization process.

EROJE, M. A.; FAWEHINMI, H. B.; JAJA, B. N. \& YAAKOR, L. Índice cefálico de la tribu Ogbia del estado de Bayelsa. Int. J. Morphol., 28(2):389-392, 2010.

RESUMEN: Se estudió el índice cefálico en sujetos de la tribu Ogbia del estado de Bayelsa en la región del Delta del Níger de Nigeria. Fueron seleccionados al azar 440 individuos de la comunidad ( 219 hombres y 221 mujeres), con edades entre 2 y 18 años. La longitud y el ancho de la cabeza se midió utilizando un caliper de referencias óseas estándar. La longitud de la cabeza se midió entre la glabela y el opistocranion, y el ancho a nivel parietal desde un euryon a otro. Los valores medios de índice cefálico, la desviación estándar y el error estándar de la media se calcularon para ambos sexos. El resultado mostró que el índice cefálico promedio fue de 72,96 $\pm 6,12$. Los hombres tenían un índice cefálico de $73,68 \pm 6,53$, mientras que las mujeres mostraron una índice cefálico de 72,24 $\pm 5,60$. La diferencia en el índice cefálico entre hombres y mujeres fue significativa $(\mathrm{p}=0,007)$. Con base en el índice cefálico, el 66,82\% de los individuos eran dolicocefálicos, el 21,59\% mesocefálicos, el 10,23\% braquicefálicos y el 1,36\% hiperbraquicéfalicos. Esta investigación mostró que los niños Ogbia tienen un fenotipo dolicocefálico. Los datos de esta investigación pueden ser útiles en antropología, genética y medicina forense.

PALABRAS CLAVE: Índice cefálico; Dolicocefálico; Ogbia; Medicina forense.

\section{REFERENCES}

Abolhasanzadeh, A. \& Farahani, M. R. Standarded international classification of head shapes of 22-24 years old in Tehran. J. of Research in Medicine, 26:281-5, 2003.

Buretic'-Tomljanovic', A.; Ristic', S.; Brajenovic'-Milic',
B.; Ostojic', S.; Gombac, E. \& Kapovic', M. Secular change in body height and cephalic index of Croatian medical students (University of Rijeka). Am. J. Phys. Anthropol., 123(1):91-6, 2003.

Bhargava, I. \& Kher, G. A. An anthropometric study of Cen- 
tral India Bhils of Dhar district of Madhya Pradesh. $J$. Anat. Soc. India, 9:14-9, 1960.

Bhargava, I. \& Kher, G. A. A comparative anthropometric study of Bhils and Barelas of Central India. J. Anat. Soc. India, 10:26-33, 1961.

Bhatia, M.; Thin, J.; Debray, H. \& Cabanes, J. Etude anthropologique et genetique de la population du nord de l'Inde. Bull. Et Mem. Soc. d'Anthrop. de Paris, 10:199-213, 1995.

Del Sol, M. Cephalic index in a group of mapuche individuals in the IX Region of Chile. Int. J. Morphol., 23(3):241-6, 2005.

Fawehinmi, H. B.; Osunwoke, A. E.; Ligha, A. E. \& Okoh, P. D. A comparative study on the cephalic indices of normal growing children and children with sickle cell anaemia in Port Harcourt. J. Exp. \& Clin. Anat., 7(1): 27-9, 2008.

Golalipour, M. J.; Haidari, K.; Jahanshahi, M. \& Frahani, M. R. The shapes of head and face in normal male newborns in South-East of Caspian Sea (Iran-Gorgan). J. Anat. Soc. India, 52:28-31, 2003.

Golalipour, M. J.; Jahanshali, M. \& Haidari, K. The variation of head and face shapes in females newborns in the southeast of the Caspian sea (mean Gorgam). Eur. J. Anat., 9(2):95-8, 2005.

Golalipour, M. J.; Jahanshahi, M. \& Haidari, K. Morphological evaluation of head in Turkman males in Gorgan-North of Iran. Int. J. Morphol., 25(1):99-102, 2007.

Golam, H. M.; Lestrel, P. E. \& Ohtsuki, F. Secular changes in head dimensions of Japanese females over eight decades. Anthropol. Sci., 112(3):213-8, 2004.

Grant, T. M. \& Peter, A. M. Size and shape measurement in contemporary cephalimeyrics. Eur. J. Orthod., 25:23142, 2003.

Heravi, F. \& Zieaee, H. Assessing the importance of cephalic and facial indices in a group of 12 years old boys in Mashhad. Beheshti Univ. Dent. J., 20:119-24, 2002.

Kelly, K. M.; Littlefield, T. R.; Pomatto, J. K.; Riphley, C. E.; Beals S. P. \& Joganic, E. F. Importance of early recognition and treatment of deformational plagiocephaly with orthotic cranioplasty. Cleft Palate Craniofac. J., 36:127-30, 1999.
Kouchi, M. Brachycephalization in Japan has ceased. Am. J. Phys. Anthropol., 112:339-47, 2000.

Larsen, C. S. Bioarcheology. Cambridge, Cambridge University Press, 1997.

Lobo, S. W.; Chandrashekhar, T. S. \& Kumar, S. Cephalic index of Gurung community of Nepal--an anthropometric study. Kathmandu Univ. Med. $J$. (KUMJ), 3(3):263-26, 2005.

Oladipo, G. S. \& Olotu, J. Anthropometric comparison of cephalic indices between the Ijaw and Igbo tribes. Global Jnl. Pure and Applied Sciences, 12(1):137-8, 2006.

Olotu, J.; Eroje, A.; Oladipo, G. \& Edibamode, E. Anthropometric study of the facial and nasal length of adult Igbo ethnic group in Nigeria. Internet J. Biol. Anthropol., 2(2), 2009.

Rajlakshmi, C. H.; Shyamo Singh, M.; Bidhumukhi, T. H. \& Chandramani, S. L. Cephalic index of fetuses of Manipuri population. A baseline study. J. Anat. Soc. India, 50(1):13-6, 2001.

Sekla, B. \& Soukup, F. Inheritance of the cephalic index. Am. J. Phys. Anthrop., 30(1):137-40, 2005.

Shah, G. V. \& Jadhav, H. R. The study of cephalic index in students of Gujarat. J. Anat. Soc. India, 53(1):25-6, 2004.

Williams, P.; Dyson, M.; Dussak, J. E.; Bannister, L. H.; Berry, M. M.; Collins, P. \& Ferguson, M. W. J. Gray's anatomy. Skeletal system. $38^{\text {th }}$ Edn. London, Elbs with Churchill Livingston, 1995. pp.607-12.

\section{Correspondence to:}

Ahmed Eroje M.

Department of Anatomy

Niger Delta University

Wilberforce Island, Amassoma

Bayelsa State, NIGERIA

$+2348059151030$

$+2348032419691$

Email:a_erodje@yahoo.com 